\title{
Optimizing the Synthesis of Lignin Derivatives from Acacia mangium to Improve the Enzymatic Hydrolysis of Kraft Pulp Sorghum Bagasse
}

\author{
Widya Fatriasaria ${ }^{*}$, Fajar Nur Hamzahb ${ }^{b}$ Bagas Ikhsan Pratomo ${ }^{c}$, Triyani Fajriutamia, \\ Riksfardini Anissa Ermawara, Faizatul Falaha, Raden Permana Budi Laksana ${ }^{a}$, \\ Muhammad Ghozalid, Apri Heri Iswanto ${ }^{\mathrm{e}}$, Euis Hermiatia ${ }^{\mathrm{a}}$ Ina Winarnif \\ ${ }^{a}$ Research Center for Biomaterials, Indonesian Institute for Sciences, Jl Raya Bogor KM 46 Cibinong 16911, Indonesia \\ ${ }^{b}$ Diploma Program for Chemical Analysis, Bogor Agricultural University, Bogor 16151, Indonesia \\ cDepartment of Chemistry, Faculty of Mathematics and Science, University of Gajah Mada, sekip Utara, Bulaksumur, Yogyakarta 5528, \\ Indonesia \\ ${ }^{d}$ Research Center for Chemistry- LIPI, Kawasan PUSPITEK, Muncul, Serpong, 15314, Indonesia \\ eDepartment of Forest Product, Faculty of Forestry, Universitas Sumatera Utara, Kampus USU, Padang Bulan, Medan, Sumatera \\ Utara, Indonesia
}

fThe Center for Research and Development on Forest Products, Jl Gunung Batu No 5, Bogor 16610, Indonesia

\begin{abstract}
The present study is aimed at optimizing the synthesis of Amphipilic lignin derivatives (A-LD) from the isolated lignin of A.mangium black liquor (BL), using the one and two step acid isolation method, and commercial lignin (LS) was used as comparison. The experimental design was conducted using Taguchi method, which consisted of four parameters and two level factors, with reference to the matrix orthogonal array, $\mathrm{L}_{8}$, including temperature, reaction time, amount of polyethylene glycol diglycidylethers (PEGDE) and Kraft lignin (KL). Furthermore, the kraft pulp of sweet sorghum bagasse (SSB) was used as substrate in the enzymatic hydrolysis (NREL method), with addition of A-LD, whose functional group and surface tension were then characterised using ATR-FTIR and surface tension equipment. Conversely, an improvement in the reducing sugar yield (RSY) compared to the control was observed after adding various ALDs to the substrate during enzymatic hydrolysis. This product was more prospective for $\mathrm{L}_{2} \mathrm{~S}$ than others products under milder circumstances, due to the fact that it possesses the lowest surface tension. Also, Taguchi analysis demonstrated the treatment at $60{ }^{\circ} \mathrm{C}$ for $1 \mathrm{~h}$ with $3.0 \mathrm{~g}$ and $0.6 \mathrm{~g}$ of PEDGE and lignin, respectively as the optimum condition, while the amount of lignin present was included as a factor with the propensity to significantly affect A-LD $\mathrm{L}_{1} \mathrm{~S}$ and LS. Therefore, it was established that the A-LDs from A. mangium kraft lignin require milder synthesis conditions, compared to other existing methods and despite the differences in optimum experimental condition for $\mathrm{L}_{2} \mathrm{~S}$ and LS, the functional groups in the IR spectra possessed very identical characteristics. C2020. CBIORE-IJRED. All rights reserved
\end{abstract}

Keywords: Amphipilic Lignin Derivatives, lignin, reducing sugar yield, Optimization, Taguchi analysis, A-LD synthesis

Article History: Received : $23^{\text {rd }}$ January 2020; revised: $16^{\text {th }}$ April 2020; Accepted: 25 th April 2020; Available online: $4^{\text {th }}$ May 2020

How to Cite This Article: Fatriasari, W., Hamzah, F.N., Pratomo, B.I., Fajriutami, T., Ermawar, R.A., Falah, F., Laksana, R.P.B., Ghozali, M., Iswanto, A.H., Hermiati, E., Winarni, I. (2020) Optimizing the Synthesis of Lignin Derivatives from Acacia mangium to Improve the Enzymatic Hydrolysis of Kraft Pulp Sorghum Bagasse. International Journal of Renewable Energy Development, 9(2), 227-235

https://doi.org/10.14710/ijred.9.2.227-235

\section{Introduction}

Lignin polymer is the second most abundant biopolymer after cellulose from the lignocellulosic biomass. The biorefinery concept efficiency is increased by converting lignin, a by-product obtained from the pre-treatment stage of second generation bioethanol production, into a valueadded material. Conversely, technical lignin is usually isolated from black liquor (BL) as by-product in pulp and paper industries. Pulp and paper industries has important contribution on Indonesian national economy because of this massive labour absorption and national export income (Ahmad et al. 2018). In 2015, Indonesia is listed on top 20 global pulp and paper producer i.e. the $6^{\text {th }}$ and $10^{\text {th }}$ for paper and pulp, respectively. With assumption annual growth of $3 \%$, the pulp production capacity is forecasted about 11.6 million tons in 2020 (Asosiasi Pulp dan Kertas Indonesia, APKI 2016)..

\footnotetext{
* Corresponding author: widya.fatriasari@biomaterial.lipi.go.id
} 
Silsia et al. (2011) reported a conventional pulping yield of $42.59 \%$, and the isolate of kraft lignin obtained from Acacia mangium BL was $45.76 \%$ (Hermiati et al. 2017). Furthermore, about $50 \%$ and $36 \%$ of the yield have been adopted as heat source in pulp mills, and for electricity generation, respectively (Mercer International Groups 2008). The potency of BL and lignin is predicted to be 6.66 and 3.05 million tons, respectively, where about 0.43 million tons of lignin (14\%) is un-utilized as loss, hence the tendency for use as a valuable bioproduct. In addition, it is also possible to improve the efficiency of enzymatic hydrolysis during bioethanol production, using the resulting biosurfactant. This is attained through integration with the manufacturing process of pulp and paper mills. Conversely, the demand of surfactant in Indonesia has reached 95 thousand tons per year, while the domestic production capacity is limited to 55 thousand (www.lipi.go.id), hence the need to import approximately 40 thousand. Meanwhile, the wide use of surfactant, alongside the high domestic consumption facilitates the development of affiliated industries. These amphiphilic substances are known to contain hydrophilic molecules (water-soluble ionic groups) and hydrophobic (oil-soluble hydrocarbon) chains, with the ability to change a materials' surface property. Furthermore, they are soluble in water, as well as organic solvent (Uraki et al. 2012), due to the capability of decreasing surface and interfacial tension, improving the stability of dispersed particles, and also controlling the type of emulsion formed. For example, oil in water $(\mathrm{O} / \mathrm{W})$ or water in oil $(\mathrm{W} / \mathrm{O})$ emulsions (Swasono et al. 2012). Furthermore, Amphipilic lignin derivatives (A-LD) are one of the lignin-based non-ionic surfactant, which is mainly utilized in elevating the efficiency of hydrolysis, as well as to improve the fermentation by yeast. Cheng et al. (2014) reported on the ability for A-LDs (DOPEG-SL and EPEG-SL) to improve the production of bioethanol during fed-batch simultaneous saccharification and fermentation (SSF). This $1.5 \mathrm{~L}$ unit with a substrate loading of $30 \%(\mathrm{w} / \mathrm{v})$ generates high concentrations of $87.9 \mathrm{~g} / \mathrm{L}$ at temperature of $38^{\circ} \mathrm{C}$, after adding $3.0 \mathrm{~g} / \mathrm{L} \mathrm{A}-\mathrm{LDs}$ (Cheng et al. 2017).

It is assumed that these molecules confer stability on the enzyme responsible for denaturation during the process of enzymatic hydrolysis(Uraki et al. 2012; Kaar and Holtzapple 1998; Lee et al. 1996), and also the function as a cellulase-aid agent (Uraki et al. 2012). Previously, A-LDs have been developed from the acetic acid lignin (AL) and technical lignin via polyoxyethylation reaction. This requires the adsorption of epoxidized polyethylene glycol (PEGs) on the surface, subsequently serving as the hydrophilic moiety, including dodecyloxypoly(ethylene glycol) glycidyl ether (DOPEG), ethoxy (2-hydroxy) propoxy poly (ethylene glycol) glycidyl ether (EPEG), dodecyloxy-polyethylene glycol glycidyl ether (DAEO) and polyethylene glycol diglycidyl ethers (PEDGE) (Cheng et al. 2014; Homma et al. 2008; 2010; Winarni et al. 2013). In addition, the steric action of the bound lignin surface undergoes a hydrophobic interaction competition between the proteins and surfactants. This further reduces the possibility of un-reproductive enzyme bonding, facilitating the effectiveness of total enzyme applied in the hydrolysis process (Jeon et al. 1991; Börjesson et al.2007).

A-LDs are also affiliated with the maintenance of high enzyme activity and significantly improved recovery after the saccharification process (Uraki et al. 2001; Winarni et al. 2014; Winarni et al. 2013). Meanwhile, surfactants tend to prevent the incidence of reinteraction with the lignin, consequently increasing the possibility of enzyme re-use after reaction completion. Specifically, A$\mathrm{LD}$ as a water soluble polymer prevents the incidence of non-reproductive absorption (Winarni et al. 2013). Based on the granted patent No US 8911976-B2 in 2014, there has been reports on the development of lignin surfactant derived from kraft, acetic, organosolv, steam explosion, sulphate, as well as alkali lignin from softwood (cedar, cypress and pine), hardwood (beech and oak), and Gramineae (rice straw, fir, bagasse). However, the type sourced from kraft lignin Indonesia has not been developed to serve biosurfactant, purposes as the A-LDs synthesized by Winarni et al.(2013) from the acetic lignin of cedar wood and sago alkali lignin.

Previously, Fatriasari et al. (2017) reported on the improvement of reducing sugar yield (RSY) after adding crude A-LD in the enzymatic hydrolysis of kraft pulp of sweet sorghum bagasse (SSB). Hence, the incorporation of a $5 \%$ crude loading was proposed for use in the reaction. This process involved the integration of isolated kraft lignin sourced from A.mangiumwith PEDGE, possessing a molecular weight $(\mathrm{Mn})$ of 500, which demonstrated better synthesis performance, resulting in a higher RSY. In addition a better effect is attained through the optimization of synthesis condition and parameters. This has not been reported in any study to our best knowledge, as A-LD synthesis was conducted using the Taguchi method, which is well-known for simplicity and ease, consequently adopted for improved process quality and diminished production cost (Roy 1990). This approach is particularly adopted in the microwave based heating of cellulosic biomass, leading to reduced variation in parameter combination (Tseng et al. 2013), as well as the optimization of some other process, including the biodiesel production of soybean waste (Fajriutami et al.2013).Therefore, Taguchi method adopted in the discovery of optimal parameters for A-LD synthesis, hence the product is subsequently added to the enzymatic hydrolysis of pulp sourced from kraft SSB. This was performed in an attempt to observe the effects on RSY. The aim of this study was to optimize the A-LD synthesis condition by using Taguchi method. Isolated lignin from A.mangium $\mathrm{BL}$ with one and two step method was used in A-LD synthesis.

\section{Materials and Methods}

\subsection{Materials}

Black liquor (BL) of $A$. mangium kraft pulping, characterized by $70 \%$ solid content, was obtained from PT TELPP, South Sumatera, Indonesia, and used as a lignin source in A-LD synthesis. For comparison, commercial lignin (LS), Sigma Aldrich, was also subjected to a similar design condition. Epoxylated PEG, i.e polyethylene glycol diglycidyl ethers (PEDGE) Mn 500 (analytical grade, Sigma-Aldrich) was adopted as hydrophilic molecules, while SSB pulped with $17 \%$ active alkali and $20 \%$ sulfidity at $170^{\circ} \mathrm{C}$ for $4 \mathrm{~h}$ was used as enzymatic hydrolysis substrate (Fatriasari et al. 2015). This condition was selected because prior study demonstrated the propensity to generate the highest RSY (Solihat et al.2017). 
Conversely, cellulase enzyme (celluclast) ATCC 26921 acquired from Trichoderma reesei with activity of 42.3 FPU/mL (NREL/TP-510-42628) was applied in the enzymatic hydrolysis of kraft pulp SSB.

\subsection{Methods}

\section{2.1 Lignin Isolation}

A.mangium $\mathrm{BL}$ was isolated using the one and two step acid isolation method according to Hermiati et al. (2017), with modification in the frequency of washing the solution. Furthermore, 1 mole/L of hydrochloric acid $(\mathrm{HCl})$ was added to $100 \mathrm{~g}$ BL with $\mathrm{pH} 12$ and above, in order to reduce the value to 2 , while ethanol was incorporated at a $\mathrm{pH}$ of 7 , in an attempt to remove the sugar embedded in solution. Meanwhile, lignin suspended in acid solution was reserved for $8 \mathrm{~h}$, to ensure complete precipitation, which was followed by vacuum filtration, in order to achieve a separation from solution. The precipitates were then dried at $45^{\circ} \mathrm{C}$ for $24 \mathrm{~h}$, and the lignin isolates, $\mathrm{L}_{1} \mathrm{~S}$ (one step) and $\mathrm{L}_{2} \mathrm{~S}$ (two step), were grounded and sieved through mesh 40. Consequently, the individual moisture content was determined prior to use in the process of A-LD synthesis.

\subsubsection{A-LD synthesis based on Taguchi statistical design}

The product quality is possibly improved with the Taguchi method by reducing the impact of factor variations, including the application of orthogonal arrays to lessen the experiment frequency. Furthermore, signal to noise ratio $(S / N)$ is used to determine and evaluate the quality characteristics of different parameter combinations, subsequently predict and verify the optimal values (Tseng et al. 2013).

A-LD synthesis was performed based on Taguchi design with matrix $\mathbf{L}_{\mathbf{n}}(\mathbf{l} \mathbf{f})$, and conducted to detect the effect of temperature, reaction time, amount of lignin, and PEDGE. Conversely, the RSY per biomass was adopted as response parameter, with independent variables of temperature at $60^{\circ} \mathrm{C}$ and $70{ }^{\circ} \mathrm{C}$, reaction time $(1$ and $2 \mathrm{~h})$, amount of PEDGE (2 and $3 \mathrm{~g}$ ) and lignin (0.6 and $1 \mathrm{~g}$ ) during A-LD synthesis. The orthogonal matrix design selected for variable was $\mathrm{L}_{8}\left(2^{3}\right)$, being the smallest factorial, where the level chosen was (l), with 2 and 4 factors (f), respectively. In addition, the software Minitab series 17 was used to determine the experimental design. A-LD synthesis was conducted in duplicate, based on modified Cheng et al (2014).

Table 1.

\begin{tabular}{ccccc}
\multicolumn{2}{c}{ Experiment design $\mathrm{L}_{8}\left(2^{3}\right)$} \\
\hline $\begin{array}{c}\text { Synthesis } \\
\text { condition }\end{array}$ & $\begin{array}{c}\text { Temp } \\
\left({ }^{\circ} \mathrm{C}\right)\end{array}$ & $\begin{array}{c}\text { Reaction } \\
\text { time }(\mathrm{h})\end{array}$ & $\begin{array}{c}\text { PEDGE } \\
(\mathrm{g})\end{array}$ & $\begin{array}{c}\text { Lignin } \\
(\mathrm{g})\end{array}$ \\
\cline { 2 - 5 } & 60 & 1.0 & 2.0 & 0.6 \\
1 & 60 & 1.0 & 3.0 & 1.0 \\
2 & 60 & 2.0 & 2.0 & 1.0 \\
3 & 60 & 2.0 & 3.0 & 0.6 \\
4 & 70 & 1.0 & 2.0 & 1.0 \\
5 & 70 & 1.0 & 3.0 & 0.6 \\
6 & 70 & 2.0 & 2.0 & 0.6 \\
7 & 70 & 2.0 & 3.0 & 1.0 \\
8 & & & &
\end{tabular}

Furthermore, lignin stock was prepared by dissolving lignin $\left(\mathrm{L}_{1} \mathrm{~S}, \mathrm{~L}_{2} \mathrm{~S}, \mathrm{LS}\right)$ in $1 \mathrm{M}$ aqueous $\mathrm{NaOH}$, followed by the addition of PEDGE to the $10 \mathrm{~mL}$ reaction tube. This was then placed in a beaker glass containing heated distilled water set at the temperature and reaction time stated in Table 1. In addition, the reaction was continuously stirred to attain homogeneity. Subsequently, the process was terminated through the dropwise incorporation of glacial acetic acid $(2-4 \mathrm{~mL})$ at $\mathrm{pH} 4$, leading to the formation of an emulsion. This was placed in a tightly covered vial bottle, and reserved in a refrigerator prior to use in enzymatic hydrolysis.

\subsubsection{Enzymatic hydrolysis and reducing sugar analysis}

The effectiveness of crude A-LD added to the substrate in the enzymatic hydrolysis of kraft pulp SSB was evaluated using the National Renewable Energy Laboratory (NREL) method. This involved placing about $0.2 \mathrm{~g}$ of oven dried (OD) pulp in a conical flask, followed by the addition of 200 $\mu \mathrm{l} 2 \% \mathrm{~b} / \mathrm{v}$ sodium azide, $10 \mathrm{~mL}$ sodium citrate buffer $(0.05$ $\mathrm{M}, \mathrm{pH}$ 4.8), $30 \mathrm{FPU} / \mathrm{g}$ substrate of cellulase enzyme, and $5 \% \mathrm{~A}-\mathrm{LD} / \mathrm{OD}$ substrate. Prior to use, the A-LD stock at a concentration of $15 \mathrm{mg} / \mathrm{mL}$ was dissolved in citrate buffer, which was used to adjust the samples by $20 \mathrm{~g}$, followed by incubation in an incubator shaker (WiseCube WIS-30R) at a rate of $150 \mathrm{rpm}$, and $50{ }^{\circ} \mathrm{C}$ for $72 \mathrm{~h}$. Conversely, the control of substrate, enzyme, and buffer were also considered alongside the samples, and the hydrolysis process was performed in duplicate. Furthermore, the hydrolyzed substrates were then centrifugated at $500 \mathrm{rpm}$ for $5 \mathrm{~min}$ to separate the supernatant from the residue, which was specifically placed in a freezer at temperatures of $5-10{ }^{\circ} \mathrm{C}$. Therefore, the reducing sugar analysis was conducted on the supernatant following DNS method (Miller 1959) using UV-Vis Hitachi U-2001 at wavenumber of $540 \mathrm{~nm}$. Subsequently, quality characteristics were evaluated with Taguchi statistical analysis, using the equation of Larger, which is better calculated with Minitab 17 statistical software. Based on this assessment, the equation obtained from ANOVA is possibly used to analyse data, followed by the determination of significant factors of the response, and model accuracy.

\subsubsection{Functional group analysis and surface tension}

The Attenuated Total Reflectance-Fourier Transform Infra-Red (ATR)-FTIR (a spectrum two Perkin Elmer, Shelton, USA) was used to characterize the functional groups of $\mathrm{A}-\mathrm{LD} \mathrm{L}_{1} \mathrm{~S}, \mathrm{~L}_{2} \mathrm{~S}$ and $\mathrm{LS}$, in the optimum synthesis condition. Subsequently, approximately $0.1 \mathrm{mg}$ of each was placed in a plate and hand-pressed, then the IR spectra were recorded using the scan number of 10 per sample. This was performed in the absorption mode and at a spectral resolution of $4.0 \mathrm{~cm}^{-1}$, within the range of 4000 to $600 \mathrm{~cm}^{-1}$, using the software (Perkin Elmer, USA). The surface tension of A-LDs in the optimum condition was measured using Spinning Drop Tensiometer using the method of SOP TX 500D Full Range interfacial Tensiometer. 


\section{Results and Discussions}

\subsection{The effect of lignin sources in A-LD on RSY}

Lignin is known to dissolve in alkali, including $\mathrm{NaOH}$. Furthermore, Cheng et al. (2014) reported on the absence of sediment formation in completed A-LD reactions, after the addition of glacial acetic to attain $\mathrm{pH} 4$. Fig. 1 shows the proposed reaction between A.mangium KL and PEDGE in A-LD surfactant, and no significant differences were identified with the physical characteristics of $\mathrm{L}_{1} \mathrm{~S}$, $\mathrm{L}_{2} \mathrm{~S}$, and LS biosurfactant. Previous reports have demonstrate the presence of higher acid insoluble lignin (AIL) content in $\mathrm{L}_{2} \mathrm{~S}$ than $\mathrm{L}_{1} \mathrm{~S}$, while the acid soluble lignin (ASL) composition was vice versa. In addition, the smaller particle size of $\mathrm{L}_{2} \mathrm{~S}$ was affiliated with the creation of a larger surface area, which is characterized by a relatively brighter colouration compared to $\mathrm{L}_{1} \mathrm{~S}$ (Hermiati et al. 2017). Meanwhile, both A-LDs tend to possess an unpleasant odor, due to the inherent chemical compounds, encompassing methyl mercaptan, dimethyl sulfide $\left(\left(\mathrm{CH}_{3}\right)_{2} \mathrm{~S}\right)$ and dimethyl disulfide $\left(\mathrm{CH}_{3}-\mathrm{S}-\mathrm{S}-\mathrm{CH}_{3}\right)$ (Gilligan and Pyle 1974). The formation of these gases is initiated by the break down reaction of methyl aryl ether in one of the lignin composing units.

Polyethylene and its derivatives were applied as hydrophilic molecules because of the characteristic ability to degrade easily in nature, with low toxicity level. However, epoxidized polyethylene was synthesized as the result of a reaction between polyethylene glycol (PEG) and epichlorohydrin in the $\mathrm{BF}_{3}$-Dibutylamine-Complex of PEG. This process was terminated by the incorporation of dehydrochlorination in base condition (Lin et al. 2014).

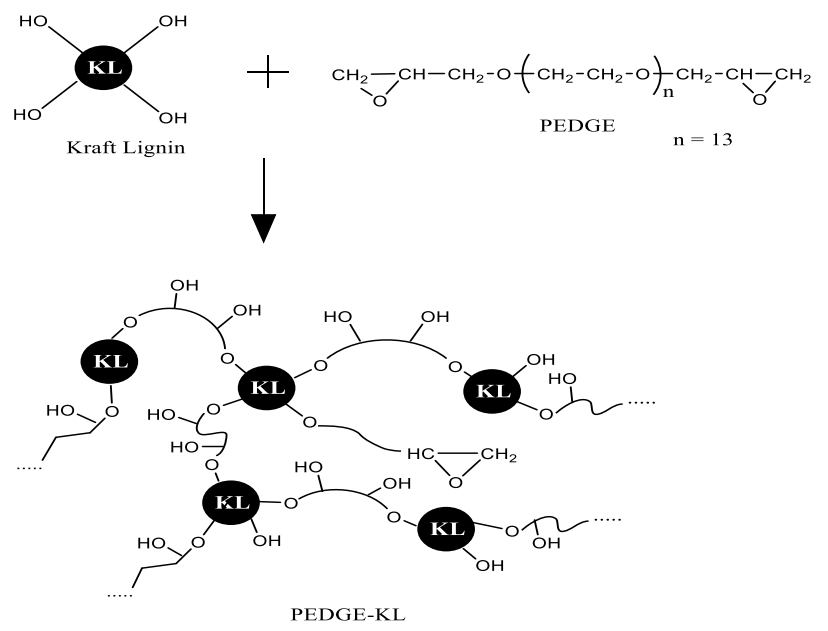

Fig.1. Proposed reaction of PEDGE and A.mangium kraft lignin (KL) on A-LD synthesis

Furthermore, PEDGE demonstrated hydrophilic attributes, hence the tendency to facilitate the water solubility properties of A-LD. These characteristics are due to the presence of oxide ethylene unit on the structure, which is enhanced in the presence of more replications (Homma et al. 2008). Moreover, the addition of hydrophilic PEGs for derivatization of hydrophobic lignin has been proven to improve surface activity. Furthermore, the addition of A-LD significantly lowered the surface tension of water (Uraki et al. 2012). Therefore, the results of adding A-LD to kraft pulp SSB show higher RSY per biomass (75.99\%) in $\mathrm{L}_{1} \mathrm{~S}$, compared with the control (Fig.2a), and obtained in experiment condition 2. This was characterized by a synthesis temperature of $60{ }^{\circ} \mathrm{C}$, reaction time of $1 \mathrm{~h}$, with the amount of PEGDE and lignin, at $3.0 \mathrm{~g}$ and $1.0 \mathrm{~g}$, respectively. However, the outcome was slight lower than the report of Fatriasari et al. (2017), which used similar A-LD loading, although the current study used milder synthesis condition, encompassing lower temperature and shorter reaction time.
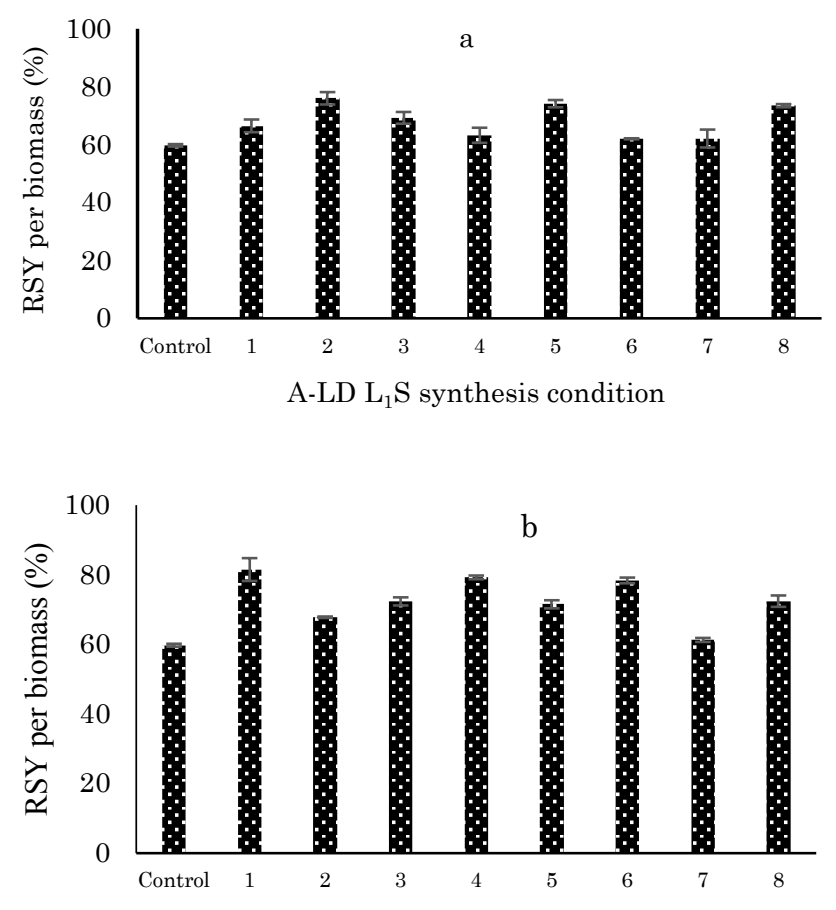

A-LD $\mathrm{L}_{2} \mathrm{~S}$ synthesis condition

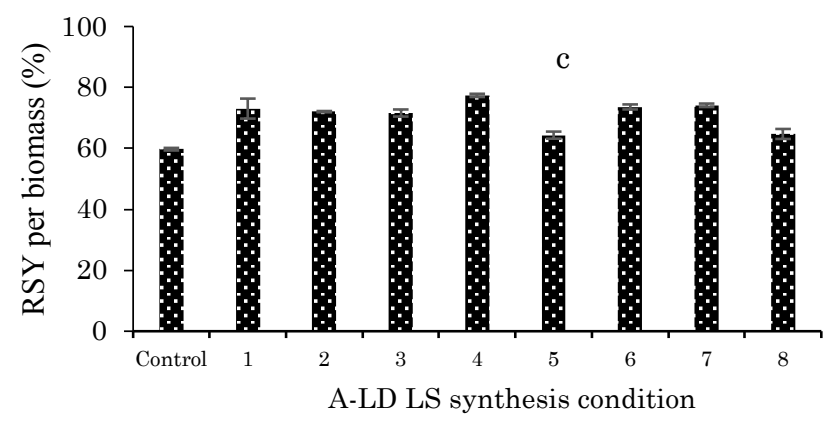

Fig. 2. Reducing sugar yield after addition of A-LD $\mathrm{L}_{1} \mathrm{~S}$ (a), A-LD $\mathrm{L}_{2} \mathrm{~S}$ (b), A-LD LS (c) in enzymatic hydrolysis of kraft pulp SSB

The addition of surfactant in enzymatic hydrolysis is assumed to inhibit the bonding between enzymes and lignin residue at the initiation of reaction. This further increases the possibility of subsequent enzyme reuse after completing the process (Eriksson et al. 2002; Li et al. 2016). In addition, A-LD is implicated in the reduced surface tension of solution, attained through the mechanism of enzyme and lignin absorption, consequently enhancing the reaction effectiveness (Fig. 3). The addition of A-LD is possibly improved by reducing non-productive 
binding of enzyme with cellulose, as well as the nonspecific hydrophobic interaction with the lignin in biomass as substrate (Uraki et al. 2012). Conversely, there was also a competition of hydrophobic interaction between protein and surfactant, which leads to a decline in the possibility of unfavourable enzyme bonding. The mechanism of resolution involves the ability for surfactant to prevent the occurrence of a reconnection between the enzyme and lignin, subsequently increasing the chance of reuse by immobilization. Moreover, A-LD is a water soluble polymer, characterized by the capacity to prevent the absorption of non-reproductive enzyme in the reaction process (Winarni et al. 2013), leading to enhanced working effectiveness (Jeon and Andrade 1991; Börjesson et al. 2007). Using similar procedure $(72 \mathrm{~h})$, the RSY of the control, using celluclast with an enzyme loading of 30 FPU/g was higher than meicellase at $293 \mathrm{FPU} / \mathrm{g}$ (45.57\% (Solihatet al. 2017). This outcome was congruent with the report of Cheng et al. (2017), where DOPEG-SL was added in the saccharification of softwood unbleached kraft pulp (NUKP) with Genecor (GC) 220 enzyme. This subsequently resulted in higher sugar yield, and the recovery of enzyme activity, compared to the use of meicellase, hence the variation affects RSY. Therefore, the higher effectiveness of celluclast (42.3 FPU/mL) compared to meicellase (14.65 FPU/mL) is implicated in this study result.

The addition of RSY to A-LD $\mathrm{L}_{2} \mathrm{~S}$ is shown in Fig.2b, where the highest amount resulted from synthesis condition 1 , characterized by temperature of $60{ }^{\circ} \mathrm{C}$, reaction time of $1 \mathrm{~h}$, and amount of PEGDE $2.0 \mathrm{~g}$ and lignin of $0.6 \mathrm{~g}$, i.e. $81.49 \%$. Compared with the previous study of Fatriasari et al. (2017), where a lower A-LD loading of $5 \%$ with milder reaction condition was used, this current investigation provided a higher RSY. Therefore, the optimization endorsed effectively facilitates the loading and synthesis factors applied. During several experiment conditions, the RSY of $\mathrm{A}-\mathrm{LD} \mathrm{L}_{2} \mathrm{~S}$ was observed to be higher than $\mathrm{L}_{1} \mathrm{~S}$, which contains lower carbon content, despite the relatively same hydrogen, oxygen, nitrogen, and sulphur contents.

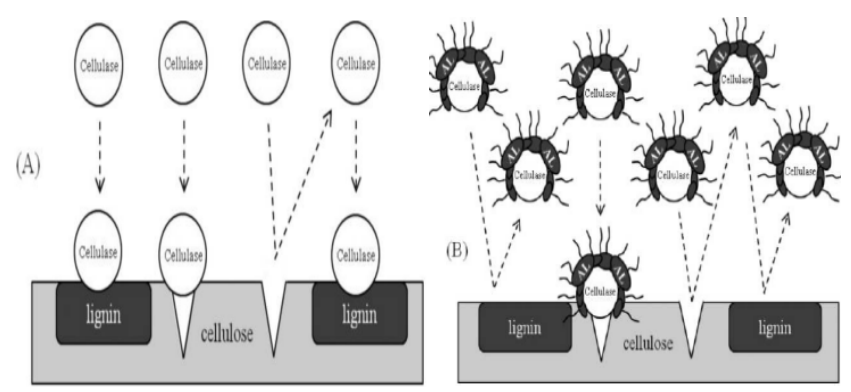

Fig. 3. Mechanism of A-LD-AL as cellulase-aid agent (a) without, and (B) with the addition of PEGDE-AL (Uraki et al. 2012)

Conversely, $\mathrm{L}_{2} \mathrm{~S}$ possesses more significant total lignin with comparably lower attachment of sugar and other impurities, although both consist of similar functional groups (Hermiati et al. 2017). Therefore, further isolation of $\mathrm{L}_{2} \mathrm{~S}$ causes a decline in the lignin yield of $\mathrm{L}_{1} \mathrm{~S}$, which affects the interaction with PEDGE in the A-LD synthesis, consequently affecting the individual sample performance in the process of enzymatic hydrolysis.

The addition of A-LD L $\mathrm{L}_{1}$ Sto EPEG and DOPEG as hydrophilic polymers in the hydrolysis of unbleached cedar pulp reported by Cheng et al. (2014) resulted in RSY yield of $70.1 \%$ and $74.3 \%$, respectively. Furthermore, the prerequisites for synthesis adopted were similar to experimental condition 4 in the current study, using $\mathrm{L}_{2} \mathrm{~S}$ and PEDGE. This yield was higher than the RSY with addition of $\mathrm{L}_{1} \mathrm{~S}$. Meanwhile, the longer reaction time and higher amount of PEDGE observed in the synthesis condition 3 with $\mathrm{L}_{2} \mathrm{~S}$, was characterized by an enhanced possibility to produce more polyethylene compounds. This facilitates the consequent reaction with lignin, therefore resulting in better A-LD characteristics. Fig. 2c shows the RSY obtained from the addition of A-LD LS in the enzymatic hydrolysis process. This involved the use of synthesis condition 4, characterized by temperature of 60 ${ }^{0} \mathrm{C}$, reaction time of $2 \mathrm{~h}$, amount of PEGDE and lignin of $2.0 \mathrm{~g}$ and $0.6 \mathrm{~g}$, respectively, which provided the highest value at $77.39 \%$. Furthermore, these prerequisites were selected as the optimum synthesis condition, although the RSY produced was comparably lower than the output obtained from adding $\mathrm{L}_{2} \mathrm{~S}$, which was the highest, and closer to $\mathrm{L}_{1} \mathrm{~S}$. Therefore, it is proposed that $\mathrm{KL}$ isolated from A.mangium BL is prospective sources of lignin for its derivatives. The RSY obtained for each treatment shows the effect of lignin isolation technique on the A-LD characteristics.

\subsection{Optimum Condition Based on Taguchi Method}

Signal to Noise $(\mathrm{S} / \mathrm{N})$ ratio, where Larger is the Better approach is used for RSY in the presence of $A-L D L_{1} S$ and $\mathrm{L}_{2} \mathrm{~S}$.This is determined based on the Taguchi method, which is chosen considering the positive value of RSY and the quality characteristic observed, as $\mathrm{S} / \mathrm{N}$ ratio demonstrates the effect of noise factor on variations in the effect of temperature, reaction time, amount of PEDGE and lignin. Fig. 4 shows the quality characteristics in presence of $\mathrm{A}-\mathrm{LD} \mathrm{L}_{1} \mathrm{~S}$, with the most influential factors exhibited with the following sequence: amount of lignin $>$ reaction time $>$ temperature $>$ amount of PEDGE.

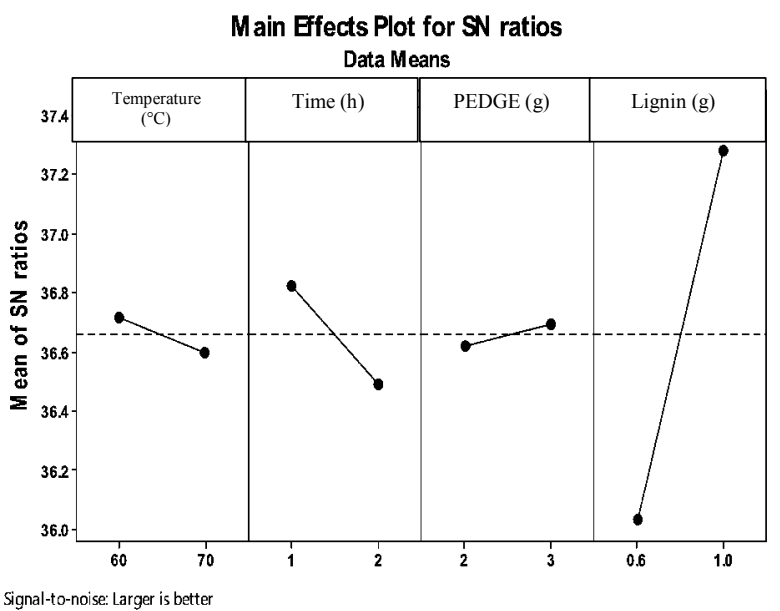

Fig. 4. Response of $\mathrm{S} / \mathrm{N}$ ratio Larger is Better in $\mathrm{A}-\mathrm{LD} \mathrm{L}_{1} \mathrm{~S}$ synthesis 
Table 2.

Analysis of Variance (ANOVA) of A-LD L $\mathrm{L}_{1} \mathrm{~S}$

\begin{tabular}{lccccccc}
\hline Factor & DF & Seq SS & Adj SS & Adj MS & F & P & F \\
\hline Temperature & 1 & 1.32 & 1.32 & 1.32 & 0.19 & 0.695 & 10.13 \\
Time & 1 & 14.06 & 14.06 & 14.06 & 1.99 & 0.253 & 10.13 \\
PEGDE & 1 & 0.91 & 0.910 & 0.91 & 0.13 & 0.744 & 10.13 \\
Lignin & 1 & 190.35 & 190.35 & 190.35 & 26.93 & $0.014^{*}$ & 10.13 \\
Residual Error & 3 & 21.20 & 21.203 & 7.07 & & & \\
Total & 7 & 227.85 & & & & & \\
\hline $\boldsymbol{a}=$ 0.05, confidence level of 95\%, *) significant factor & & & & &
\end{tabular}

$a=0.05$, confidence level of $\left.95 \%,{ }^{*}\right)$ significant factor

Analysis of variance (ANOVA) is used to determine the optimum condition for A-LD synthesis, which was performed by observing the factors and levels responsible for the significant effects on $\mathrm{L}_{1} \mathrm{~S}$ (Table 2). Furthermore, it was established that only the amount of lignin conferred a significant effect on RSY ( $\left.\mathrm{F}_{\text {count }}>\mathrm{F}_{\text {table }}\right)$. Based on $\mathrm{S} / \mathrm{N}$ ratio, the optimum condition (indicated by the highest RSY) was identified in experiment 2 , at a temperature of $60^{\circ} \mathrm{C}$, reaction time of $1 \mathrm{~h}$, amount of PEDGE and lignin of $3 \mathrm{~g}$ and $1 \mathrm{~g}$, respectively.

$\mathrm{S} / \mathrm{N}$ ratio with Larger is Better approach was also used to determine the optimum condition of A-LD $\mathrm{L}_{2} \mathrm{~S}$ (Fig. 5), which was identified as experiment 1, with temperature of $60^{\circ} \mathrm{C}$, reaction time of $1 \mathrm{~h}$, and amount of PEDGE, and lignin of $2.0 \mathrm{~g}$ and $0.6 \mathrm{~g}$, respectively. Meanwhile, the ANOVA result is presented in Table 3, which shows the absence of any significant effect from all involved factors on A-LD characteristics $\left(\mathrm{F}_{\text {count }}<\mathrm{F}_{\text {table }}\right)$ at a confidence level of $95 \%$. Therefore, $\mathrm{H}_{0}$ is accepted, as there are no dominant influencing factors in the various levels, as their close nature to one another is assumed to have an effect on the result. Despite this study outcome, it was also established that each factor confers a different effect, as observed in Fig. 5, with sequence of most influential following the order; reaction time $>$ amount of PEDGE > amount of lignin > temperature.

The optimization of A-LD LS synthesis as a control was also conducted with the Taguchi method, where Fig. 5 demonstrates the $\mathrm{S} / \mathrm{N}$ ratio with Larger is Better approach, while Table 4 presents the ANOVA results. Furthermore, the optimum synthesis condition was observed in experiment 4, characterized by a temperature of $60^{\circ} \mathrm{C}$, reaction time of $2 \mathrm{~h}, \mathrm{PEDGE}$ and lignin amount of $3 \mathrm{~g}$ and $0.6 \mathrm{~g}$, respectively. These prerequisites were compared with the optimum synthesis condition of A-LD $\mathrm{L}_{2} \mathrm{~S}$, and the need to add more PEDGE, and the exposure to longer reaction time was established. Consequently, the RSY obtained with LS was also lower, and the significant factor of synthesis, organised in the order of most influential, include amount of lignin >temperature > reaction time $>$ amount of PEDGE.

Table 3.

Analysis of Variance of A-LD L $\mathrm{L}_{2} \mathrm{~S}$

\begin{tabular}{lccccccc}
\multicolumn{1}{c}{ Factor } & DF & Seq SS & Adj SS & Adj MS & F & P & F \\
\hline Temperature & 1 & 20.29 & 20.29 & 20.29 & 0.48 & 0.540 & 10.13 \\
Time & 1 & 144.21 & 144.21 & 144.21 & 3.38 & 0.163 & 10.13 \\
PEGDE & 1 & 51.39 & 51.39 & 51.39 & 1.21 & 0.352 & 10.13 \\
Lignin & 1 & 24.16 & 24.16 & 24.16 & 0.57 & 0.506 & 10.13 \\
Residual Error & 3 & 127.8 & 127.8 & 42.63 & & & \\
Total & 7 & 367.9 & & & & & \\
\hline
\end{tabular}

$a=0.05$, Confidence level of $95 \%$, *) significant factor

Table 4.

Analysis of Variance of A-LD LS

\begin{tabular}{lccccccc}
\multicolumn{1}{c}{ Factor } & DF & Seq SS & Adj SS & Adj MS & F & P & F Table \\
\hline Temperature & 1 & 37.329 & 37.329 & 37.329 & 5.15 & 0.108 & 10.13 \\
Time & 1 & 2.865 & 2.865 & 2.865 & 0.40 & 0.574 & 10.13 \\
PEGDE & 1 & 2.684 & 2.684 & 2.684 & 0.37 & 0.586 & 10.13 \\
Lignin & 1 & 80.020 & 80.020 & 80.020 & 11.15 & $0.044^{*}$ & 10.13 \\
Residual Error & 3 & 21.741 & 7.247 & & & & \\
Total & 7 & 145.439 & & & & & \\
\hline
\end{tabular}

$a=0.05$, confidence level of $\left.95 \%,{ }^{*}\right)$ significant factor 


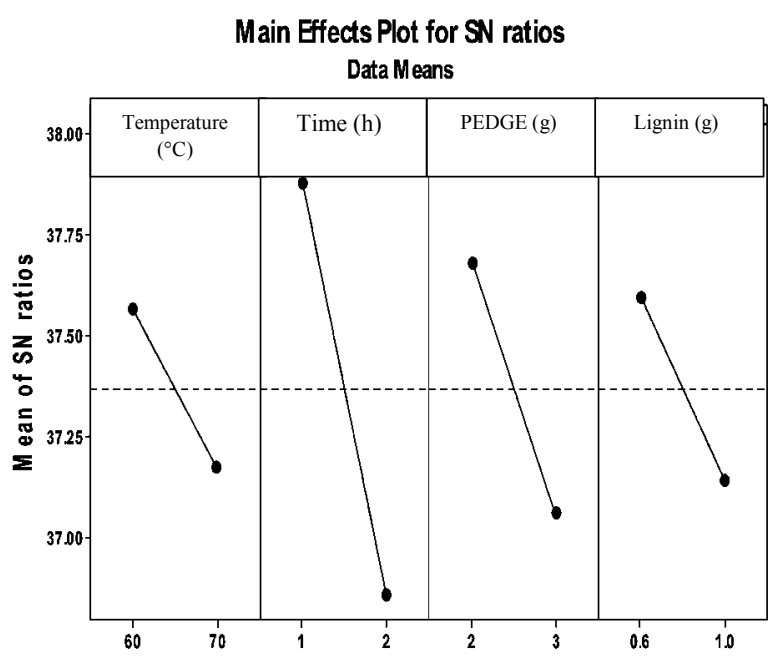

Signal-to-noise: Larger is better

Fig.5. Response $\mathrm{S} / \mathrm{N}$ ratio Larger is Better in $\mathrm{A}-\mathrm{LD} \mathrm{L}_{2} \mathrm{~S}$ synthesis

Based on the RSY obtained for each A-LDs, the synthesis condition is possibly listed on the basis of milder optimum, encompassing A-LD L $\mathrm{L}_{2} \mathrm{~S}(81.49 \%)$, LS (77.39\%), and $\mathrm{L}_{1} \mathrm{~S}$ $(75.99 \%)$. These variations were attributed to the lignin isolation method, based on the results of $\mathrm{S} / \mathrm{N}$ ratio analysis and ANOVA (Table 4). Furthermore, the presence of impurities in lignin has also been implicated as a possible influencer of A-LD characteristics. Cheng et al. (2014) reported on the propensity for epoxylated PEGs used to confer an effect on surface activity, which is independent of the lignin origin or isolation method. Previously, Winarni et al. (2013) reported on the 69\% yield from the addition of A-LD obtained from PEDGE and $\mathrm{AL}$ in enzymatic hydrolysis of cedar kraft pulp, with a cellulase loading of $20 \mathrm{FPU} / \mathrm{g}$. Furthermore, the synthesis condition used involved $10 \mathrm{~g}$ lignin, $30 \mathrm{~g}$ PEDGE, and exposure to a temperature of $70^{\circ} \mathrm{C}$ for $2 \mathrm{~h}$. Hence, a comparison with previous study showed a better RSY in optimum condition using A-LD sourced from A.mangium KL (1 and 2 step isolation), than PEDGE-AL, which was exposed to more severe conditions, compared to $\mathrm{L}_{1} \mathrm{~S}$ and $\mathrm{L}_{2} \mathrm{~S}$.

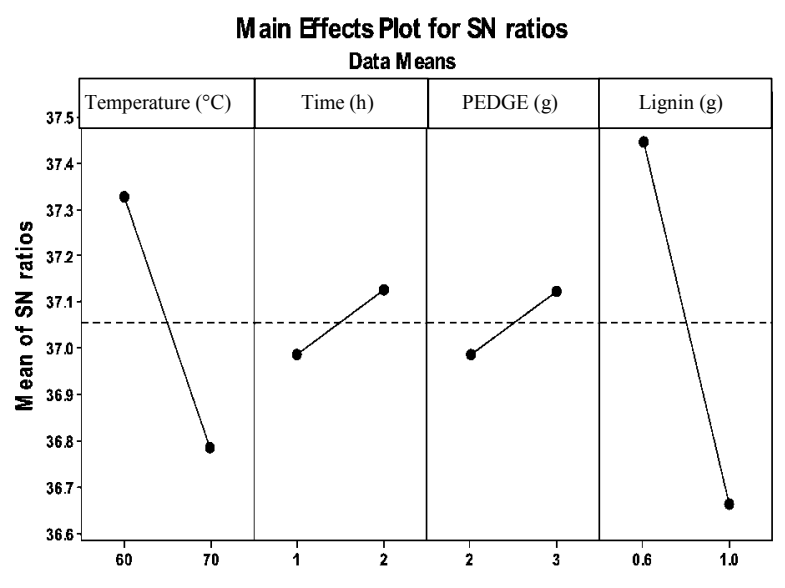

Signal-to-noise: Larger is better

Fig. 6. Response of $\mathrm{S} / \mathrm{N}$ ratio larger is better of A-LD LS
3.3 Analysis of functional groups of the optimum A-LD synthesis

The A-LDs obtained using the optimum synthesis condition was then analysed for functional group characteristics, using FTIR, as seen in Fig. 7 and Table 5. There were identical features between $\mathrm{L}_{2} \mathrm{~S}$ and $\mathrm{LS}$, compared to $\mathrm{L}_{1} \mathrm{~S}$, as some were only present in $\mathrm{L}_{2} \mathrm{~S}$ and $\mathrm{LS}$, but not $\mathrm{L}_{1} \mathrm{~S}$, including the $\mathrm{C}-\mathrm{H}$ stretch at $3000-2842 \mathrm{~cm}^{-1}$. Meanwhile, the effect of isolation method on the lignin characteristics is shown by the presence of impurities embedded in $\mathrm{L}_{1} \mathrm{~S}$, which subsequently leads to an imperfect reaction with PEGDE. Physically, the internal observation shows a darker colouration with bigger particle size compared to $\mathrm{L}_{2} \mathrm{~S}$ and LS, hence the synthesis process completion is affected by the lignin type used as a main raw material. This study outcome is supported by previous results indicating the amount of lignin included as a significant factor, leading to the formation of varying characteristics in each A-LD type. Meanwhile, all samples in optimum condition tend to demonstrate low absorption of the epoxy moiety $(\mathrm{C}=\mathrm{O})$, with weak intensity and some typical lignin absorption spectra.

Basically, the characteristic of lignin is assigned by the following groups; -OH (3460-3412 $\left.\mathrm{cm}^{-1}\right)$, C-H (3000$\left.2842 \mathrm{~cm}^{-1}\right), \mathrm{C}=\mathrm{O}\left(1738-1593 \mathrm{~cm}^{-1}\right)$, syringil $\left(1330 \mathrm{~cm}^{-1}\right)$, and $\mathrm{C}-\mathrm{H}\left(925-832 \mathrm{~cm}^{-1}\right)$ (Chen et al.2015). Furthermore, the Infrared (IR) of PEGDE shows absorption in the range of O-H groups at $3424 \mathrm{~cm}^{-1}, \mathrm{C}-\mathrm{H}$ alkane at $2885 \mathrm{~cm}^{-1},-\mathrm{CH}_{2}$ at $1464 \mathrm{~cm}^{-1}, \mathrm{C}-\mathrm{O}$ at $1183 \mathrm{~cm}^{-1}$, linier- $\mathrm{CH}_{2}-\mathrm{OCH}_{2}$ - at 1096 and $1150 \mathrm{~cm}^{-1}$, - CH- cyclic epoxy at $1647 \mathrm{~cm}^{-1}$ and epoxy groups at 837 and $1238 \mathrm{~cm}^{-1}$ (Motawie et al. 2010). Hermiati et al.(2017) also reported on the functional groups of $\mathrm{KL}$ (1 and 2 steps) isolated from A.mangiumBL, where $\mathrm{L}_{1} \mathrm{~S}$ and $\mathrm{L}_{2} \mathrm{~S}$ possess typical lignin absorption characteristics, although syringyl at wave number of 1330-1325 $\mathrm{cm}^{-1}$ was not identified. Uraki et al. (2001) reported on the IR spectra of A-LD AL-PEDGE, which showed aromatic nucleus absorption at 1590-1510 $\mathrm{cm}^{-1}$ and intense absorption at $2900 \mathrm{~cm}^{-1}$, corresponding to the presence of a C-H bond in methylene.

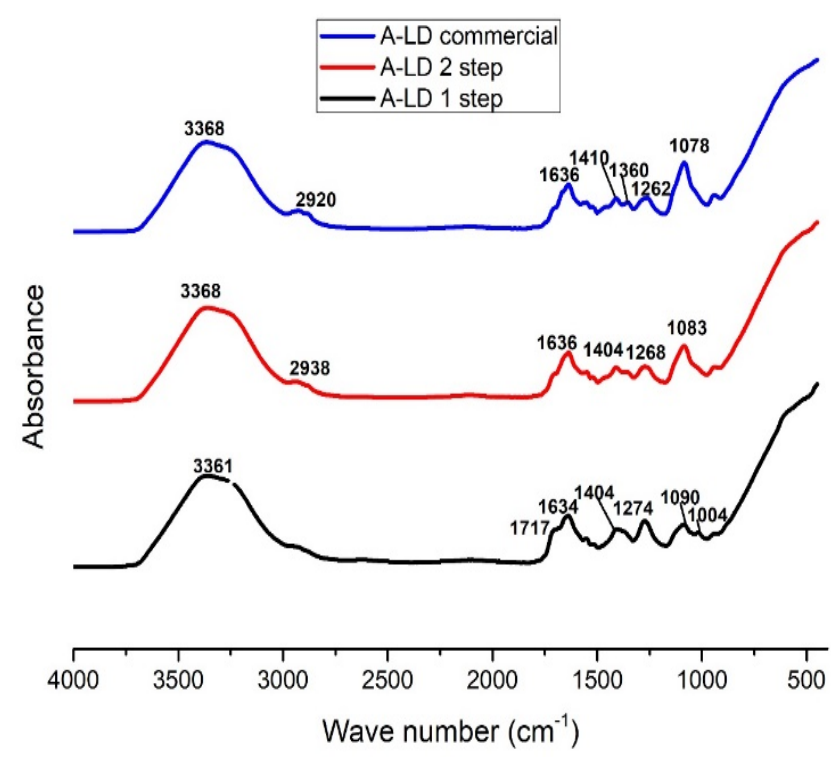

Fig. 7. FTIR spectra of A-LDs in the optimum synthesis condition 
Citation: Fatriasari, W., Hamzah, F.N., Pratomo, B.I., Fajriutami, T., Ermawar, R.A., Falah, F., Laksana, R.P.B., Ghozali, M., Iswanto, A.H., Hermiati, E., Winarni, I. (2020) Optimizing the Synthesis of Lignin Derivatives from Acacia mangium to Improve the Enzymatic Hydrolysis of Kraft Pulp Sorghum Bagasse. Int. Journal of Renewable Energy Development, 9(2), 227-235, doi: 10.14710/ijred.9.227-235

$\mathrm{P}$ a g e $\mid 234$

Table 5.

Functional groups analysis of A-LD $\mathrm{L}_{1} \mathrm{~S}, \mathrm{~A}-\mathrm{LD} \mathrm{L}_{2} \mathrm{~S}$ and A-LD LS in the optimum condition

\begin{tabular}{ccccl}
\hline A-LD L $\mathrm{L}_{1} \mathrm{~S}$ & $\mathrm{~A}-\mathrm{LD} \mathrm{L} \mathrm{L}_{2} \mathrm{~S}$ & $\mathrm{~A}-\mathrm{LD} \mathrm{LS}$ & $\begin{array}{c}\text { Wave number }\left(\mathrm{cm}-{ }^{-1}\right) \\
(\text { Chen } \text { et al.2015) }\end{array}$ & Functional groups \\
\hline 3356.95 & 3356.61 & 3356.85 & $3460-3412$ & O-H stretch \\
- & 2938.83 & 2926.73 & $3000-2842$ & C-H stretch/bond in methylene groups \\
1638.82 & 1637.45 & 1638.08 & $1675-1655$ & C=O stretch, unconjugated ketone \\
1551.06 & 1549.54 & 1551.16 & $1605-1505$ & Aromatic ring \\
- & 1525.27 & - & $1605-1505$ & Aromatic ring \\
1405.29 & 1409.26 & 1409.60 & $1470-1365$ & Asymmetric C-H in $-\mathrm{CH}_{3}$ and $\mathrm{CH}_{2}-$ \\
- & 1362.68 & 1354.46 & $1270-1365$ & C-H stretch aliphatic in $-\mathrm{CH}_{3}$ and phenol \\
1273.46 & 1272.94 & 1261.58 & $1270-1266$ & Guiacyl ring \\
1086.84 & 1084.89 & 1084.21 & 1086 & Deformation C-O on secondary alcohol \\
1017.79 & - & - & 1030 & C-H in plane aromatic \\
- & 940.19 & 942.82 & $990-966$ & -HC=CH- out of plane \\
\hline
\end{tabular}

This is present in $\mathrm{L}_{2} \mathrm{~S}$ and $\mathrm{LS}$, but absent in $\mathrm{L}_{1} \mathrm{~S}$, due to the impurities embedded, which possibly prevent the complete bond formation with PEDGE, consequently leading to a lower output of RSY. In addition, the intensity of PEDGE and lignin is decreased at wave number 1200 $\mathrm{cm}^{-1}$ and $837 \mathrm{~cm}^{-1}$, due to the assignment of epoxy and finger prints for PEDGE, and the absorption intensity of $\mathrm{C}=\mathrm{O}$ occurs at $1600 \mathrm{~cm}^{-1}$ for lignin. This is possibly caused by a reaction between both materials, involving the opening of the epoxy group, thus exposing the linking $\mathrm{O}$ atom.

\subsection{Surface Activity of A-LDs}

The feasibility of A-LD $\mathrm{L}_{1} \mathrm{~S}, \mathrm{~L}_{2} \mathrm{~S}$ and $\mathrm{LS}$ as surfactants were determined by evaluating the ability to reduce water surface tension. Consequently, the resulting preparation dissolves both in water and organic solvents, encompassing methanol, chloroform, pyridine and benzene, hence all samples depressed water surface tension (Cheng et al. 2014; Homma et al. 2008). However, the least effect was observed with PEGDE-AL, which possesses the highest ethylene oxide (EO) content (Homma et al. 2008). In this current investigation, the lowest surface tension was identified in A-LD $\mathrm{L}_{2} \mathrm{~S}$ (38.87 dyne/cm), subsequently contributing to the higher RSY produced, followed by $\mathrm{L}_{1} \mathrm{~S}$ (41.34 dyne/cm) and LS (42.73 dyne/cm), which were not congruent with the RSY produced. This manifestation was, therefore, attributed other factors, including the absence of functional groups (C-H bond in methylene groups in $\mathrm{L}_{1} \mathrm{~S}$, and aromatic ring in $\mathrm{LS}$ and $\mathrm{L}_{1} \mathrm{~S}$ ). A previous study by Cheng et al. (2014) affiliated the dependence of A-LD surface activity with the nature of corresponding epoxylated PEGs used during synthesis, resulting from the crosslink of KL by PEGDE.

\section{Conclusion}

The addition of $\mathrm{A}-\mathrm{LD} \mathrm{L}_{2} \mathrm{~S}$ in the enzymatic hydrolysis of kraft pulp SSB leads to improved RSY productivity, compared to $\mathrm{L}_{1} \mathrm{~S}$ and LS. Subsequent evaluation demonstrated the optimum synthesis condition, based on the ability to produce the highest amount of RSY. For $\mathrm{L}_{1} \mathrm{~S}$, $75.99 \%$ yield was recorded in experiment 2 , which was characterized by a temperature of $60^{\circ} \mathrm{C}$, reaction time of 1 $\mathrm{h}$, amount of PEGDE and lignin of $3.0 \mathrm{~g}$ and $1.0 \mathrm{~g}$, respectively. Moreover, a $81.49 \%$ yield was obtained in $\mathrm{L}_{2} \mathrm{~S}$, through experiment 1 (temperature of $60^{\circ} \mathrm{C}$, reaction time of $1 \mathrm{~h}$, amount of PEGDE and lignin of $2.0 \mathrm{~g}$ and 0.6 $\mathrm{g}$, respectively), while, the experiment condition 4 (temperature of $60^{\circ} \mathrm{C}$, reaction time of $2 \mathrm{~h}$, amount of PEDGE and lignin of $3.0 \mathrm{~g}$ and $0.6 \mathrm{~g}$, respectively) was the best synthesis condition for LS, with RSY of $77.39 \%$. Furthermore, it was established that the amount of lignin significantly affects $\mathrm{L}_{1} \mathrm{~S}$ and $\mathrm{LS}$, hence the ideal synthesis prerequisites for A.mangium KL requires milder condition compared to existing approaches. The method for lignin isolation used results in varied characteristics, which consequently affects the binding reaction with PEDGE. Based on identified IR spectra evaluation, there were similarities in the functional group characteristics of A-LD LS and $\mathrm{L}_{2} \mathrm{~S}$ obtained with optimum conditions, characterized by the presence of $\mathrm{C}-\mathrm{H}$ stretch at 3000-2842 $\mathrm{cm}^{-1}$, which is absent in $\mathrm{L}_{1} \mathrm{~S}$.

\section{Acknowledgments}

The authors are grateful to the Research Center for Physic, Indonesian Institute of Sciences (LIPI) for funding of competitive programs in Material, and Energy Development, and also Manufacturing Engineering FY 2017. The authors also thank the Research Center for Biomaterials, LIPI for providing the equipment and testing facilities to support this study.

\section{References}

Asosiasi Pulp dan Paper Indonesia. (2016). Opportunities and challenges of Indonesian pulp and paper industry. http://www.pptgroup.se/wpcontent/uploads/2016/02/Indonesian-Pulp-and-PaperIndustry-APKI-1.pdf. [Accessed: 4 Mei 2020]

Ahmad, T, Daryanto, A., Oktaviani, R., Priyarsono. 2018. Global value chain of Indonesian pulp and paper industry. 
Jurnal Manajemen \& Agribisnis 15(2), 118-128

Börjesson, J., Peterson, R, and Tjerneld, F. (2007). Enhanced enzymatic conversion of softwood lignocellulose by poly(ethylene glycol) addition. Enzyme Microb. Technol. 40 (4), 754-762

Chen, L, Xianhua, W, Haiping, Y, Qiang L, Di, L, Qing Y, Hanping C. (2015) Study on pyrolysis behaviors of non-woody lignins with TG-FTIR and PyGC/MS. J Analytical and Applied Pyrolysis 113, 499-507. http://dx.doi.org/10.1016/j.jaap.2015.03.018

Cheng, N., Yamamoto, Y., Koda, K., Tamai, Y., and Uraki, Y. (2014). Amphipathic lignin derivatives to accelerate simultaneous saccharification and fermentation of unbleached softwood pulp for bioethanol production. Bioresour. Technol., 173, 104-109

Cheng, N, Koda, K., Tamai, Y., Yamamoto, Y., Takasuka, T.E., and Uraki, Y. (2017). Optimization of simultaneous saccharification and fermentation conditions with amphipathic lignin derivatives for concentrated bioethanol production. Bioresour. Technol.232, 126-132

Eriksson, T., Börjesson, J., and Tjerneld, F. (2002) Mechanism of surfactant effect in enzymatic hydrolysis of lignocellulose. Enzyme Microb. Technol.31(3),353-364

Fajriutami, T., Seo, Y.C., and Chu, Y.H. (2013). Optimization of two-step catalyzed biodiesel production from soybean waste cooking oil. J. Mater. Cycles Waste Manag.,15(2),179-186

Fatriasari, W, Supriyanto, and Iswanto, A. H. (2015). The Kraft pulp and paper properties of sweet sorghum bagasse (Sorghum bicolor L Moench). J. Eng. Technol. Sci., 47(2), 149-159

Fatriasari, W, Adi, D.T.N, Laksana, R.P.B, Fajriutami, T, Raniya, R, Ghozali, M., Hermiati, E. (2017).The effect of Amphipilic lignin derivatives addition on enzymatic hydrolysis performance of kraft pulp from sorghum bagasse. IOP Conf. Series: Earth and Environmental Science. $\quad 141, \quad 012005 . \quad$ doi:10.1088/17551315/141/1/012005.

Gilligan, J.J. and Pyle J.L. (1974). The Organic Chemicals Industries in Chemistry and the Technological Backlash, New Jersey: Prentice-Hall

Husaeni. 2019. https://industri.kontan.co.id/news/industri-pulpand-kertas-masih-bertumbuh-5-di-2019 [Accessed: 11 January 2017].

Hermiati, E, Risanto, L, Lubis, M. A. R., Laksana, R.P.B., and Dewi, A.R. (2017). Chemical characterization of lignin from kraft pulping black liquor of Acacia mangium. International Symposium on Applied Chemistry (ISAC) 2016. AIP Conf. Proc. 1803, 20005, 020005-1- 020005-7

Homma, H., Kubo, S., Yamada, T., Koda, K., Matsushita, Y., and Uraki, Y. 2010. Conversion of technical lignins to amphiphilic derivatives with high surface activity. J. Wood Chem. Technol.30 (2),164-174.

Homma, H., Kubo, S., Yamada, T., Matsushita, Y., and Uraki, Y. (2008). Preparation and characterization of amphiphilic lignin derivatives as surfactants. J. Wood Chem. Technol.28 (4), 270-282.

http://lipi.go.id/berita/surfaktan-sudah-seharusnyadikembangkan-besar-besaran/778. [Accessed: 13 September 2017].

Jeon, S.I. and Andrade, J.D. (1991). Protein-surface interactions in the presence of polyethylene oxide. J. Colloid Interface Sci.142 (1),159-166

Kaar, W.E. and Holtzapple, M.T. (1998). Benefits from Tween during enzymic hydrolysis of corn stover. Biotechnol. Bioeng.,59(4), 419-427

Lee, W.G., Lee, J.S., Lee, J.P., Shin, C.S., Kim, M.S. and Park, S.C. (1996). Effect of surfactants on ethanol fermentation using glucose and cellulosic hydrolyzates. Biotechnol. Lett.,18 (3), 299-304

Li, Y, Zongping, S, Xiaoyan, G, Junhua, Z. (2016). Effects of lignin and surfactant on adsorption and hydrolysis of cellulases on cellulose. J Biotechnology for Biofuels.9 (20), 1-9

Mercer International Groups. 2008. https://www.sec.gov/Archives/edgar/data/1333274/00009 4523408000047/o39326exv99w1.htm [Accessed: 13 September 2017].

Motawie, AM, Sherif, MH, Badr, MM, Amer, A.A, Shehat, AS. (2010). Synthesis and characterization of waterborne epoxy resins for coating application. J Basic and Applied Sciences 4(6): 1376-1382

Miller, G.L. (1959). Use of dinitrosalicylic acid reagent for determination of reducing sugar. Analytical Chemistry, 31(3), 426-428.

Roy, R.K. (1990). A Primer on the Taguchi Method. Society of Manufacturing Engineers

Silsia, D, Ridwan, Y., Mucharromah, and Antonio, J. (2011). Kajian ekonomi biokraft campuran batang dan limbah cabang mangium pada berbagai kondisi pemasakan pulp. J. Ilmu Kesehat.5(2), 108-117

Solihat, N.N, Fajriutami, T., Adi, D.T.N., Fatriasari, W., and Hermiati, E. (2017). Reducing sugar production of sweet sorghum bagasse kraft pulp. AIP Conference Proceedings 1803, 20012-1-020012-8.

Swasono, A.W.P., Sianturi, P.D.E. and Masyithah, Z. (2012). Sintesis surfaktan alkil poliglikosida pari plukosa dan dodekanol dengan katalis asam. J. Tek. Kim. USU, 1(1), $5-9$.

Tseng, K-H, Shiao,Y-F, Chang,R-Fand Yeh,Y-T (2003) Optimization of microwave-based heating of cellulosic biomass using Taguchi method. Materials6(8), 34043419.

Uraki, Y, Honma, H, Yamada, T, Kubo, S and Nojiri, M (2014) Lignin-based enzyme stabilizer US 8911976 B2 Granted 16 December 2014

Uraki, Y, Koda, K, Yamada, T, Oikawa. C, Aso, T. (2012) Novel functions of non-ionic, amphiphilic lignin derivatives. ACS Symposium Series Book. 1107 Chap 13. 243-254.

Uraki, Y., Ishikawa, N., Nishida, M., Sano, Y. (2001). Preparation of Amphipilic lignin derivative as cellulose stabilizer. J.Wood Sci.47(4),301-307.

Winarni, I., Koda, K., Waluyo, T.K., Pari, G., Uraki, Y. (2014). Enzymatic saccharification of soda pulp from sago starch waste using sago lignin-based amphipatic derivatives. J. Wood Chem. Technol. 34(3), 157-168.

Winarni, I., Oikawa, C., Yamada, T., Igarashi, K., Koda, K. and Uraki, Y. (2013) Improvement of enzymatic saccharification of unbleached cedar pulp with amphipathic lignin derivatives. BioResources 8(2), 21952208 